\section{Vote of no confidence}

SIR - The crisis at London's Natural History Museum, which erupted when the corporate plan was announced on 23 April this year, has now lasted more than four months and shows no sign of ending. The essence of this crisis is that the plan will result, whatever its stated intentions, in narrowing the span of taxonomic and systematic research in this museum. And, yet, as one of our trustees, R. M. May, writes (Nature 347, 130; 1990), "without taxonomy to give shape to the bricks, the systematics to tell us how to put them together, the house of biological science is a meaningless jumble".

About a thousand letters of protest have been sent to the relevant minister by our colleagues from all over the world who recognize that this museum is the world centre for taxonomic expertise (Hansard) 177 (148), col. 18; 1990); Mr Tam Dalyell MP has several times objected to the plan in parliament (Hansard 174 (118), cols. 77-81, 1990; Hansard 174 (126), cols. 1084-1092, 1990; Hansard 175 (135), cols. 1025, 1075-1077, 1990); there have been two days of strikes; and there has been a storm of press comment, nearly all of it critical of the plan and including a swingeing leading article in Nature (346, 397; 1990). But the net result of all this protest, so far, has been that three scientists threatened with forced retirement have been temporarily reprieved - two in palaeontology and one in zoology. This is from a total of some 50 jobs under threat.

There have been no reprieves in mineralogy, botany, entomology or the library nor any significant dialogue or negotiation between management and staff. A new management structure, with imposed separation of curation from research for some 150 people, has been forced down our throats, as has also a brutal system of short-term contracts for researchers. And our prizewinning design team is still threatened with extinction. Moreover, the director's main response to the letters of protest is blandly to point out their usefulness in the search for funding, since they demonstrate that the taxonomic community of the whole world is interested in the fate of the Natural History Museum (Museums Journal 90 (8), 8; August 1990). He is right about that. But the barrage of letters also shows that the world taxonomic community has no confidence in the director nor in his plan. The scientists and designers employed in this museum similarly have no confidence in him.

We implore the new Minister for Arts, Mr David Mellor, to reject the draft of the corporate plan as now submitted to him. As motivated and competent scientists who have been working here for many years, we have a right to be heard on questions of the organization of science in this museum. Our scientific attainments and qualifications are more impressive than those of the top management.

COLIN PATTERSON (Chairman), R. P. S. JEFFERIES (Secretary), K. SATTLER , P. WHEATCROFT, (Branch Chair), JULIET CLUTTONBRock, C. J. HuMPhRIES, C. R. HILL, P. H. GREENWOOD

Science Defence Committee,

Natural History Museum,

Cromwell Road.

London SW7 5RD, UK

SIR - Beverly Halstead of the Geologists' Association (Nature 346, 406; 1990) accepts a number of points I made about the Natural History Museum. I wish to make it clear that I am a passionate supporter of the importance of museums in society and that I am disturbed at many of the events that have occurred recently in Britain.

But it is vital to understand that many museums now acknowledge that their public educational role must be carried out in a different manner from what it was some decades ago, and for good reason. Moreover, there can be no special reason why museum people should not change the way they work when change, some of it horrendous, is everywhere about. Indeed, there have been severe shortcomings in the effectiveness of the way in which many museum people have worked in the past - trustees and directors as well as security and cleaning staff.

John Evans in his letter (Nature 346, 406; 1990) misses my point about Disneyland, which is described in glowing terms as a place to work and as a place to visit. Could one really have said that about museums of the past as frequently as one would have liked.?

Finally, I note that 100 staff posts are to be lost of which 51 are scientific: is anyone worried about the other 49 posts or people even perhaps? I haven't seen a whisper about them.

DES GRIFFIN
(Chairman, Council of Australian Museum Directors)

\section{c/- The Australian Museum}

6-8 College St

Sydney, NSW 2000, Australia

SIR-I was shocked to hear about the decision to reduce the staff at the British Natural History Museum and the accompanying reshaping of its research programme. That this should happen in the face of the fact that scientists all over the world look to the British Natural History Museum as the repository of the finest collections of objects of natural history and to its staff for expert help in the solution of their research problems makes the contemplated change even more reprehensible.

In my own branch of study, palaeobotany, the museum has one of the finest collections of fossils in the world. Thinking that the museum was the best place for them, I handed over many of my type slides and specimens and also the figured duplicates to the museum.

In this connection, I must point out that the museum's collections belong not only to Britain but also to the entire world, irrespective of whether the material is of British origin. The museum's founders never imagined that the control of the museum would one day pass into the hands of short-sighted people who would regard its research as esoteric and peripheral. Small minds sometimes take control of things that are too big for their comprehension and, power-drunk, they start destroying, right and left, our gifts of the ages. However, the innate vitality within our heritage and also that of the general public should be able to assert itself and check such arbitrary and thoughtless ruination.

DIVYA DARSHAN PANT

Botany \& Palaeobotany Laboratory,

University of Allahabad,

106. Tagore Town,

Allahabad 211002, India

\section{Cell line ownership}

SiR-Your report on the California Supreme Court's decision of 9 July 1990 rejecting a patient's lawsuit to recover profits from research on a cell line derived from his surgically removed spleen tissue ("Tissues not for sale," Nature 346, 208; 1990 ) contains several inaccuracies.

First, although the University of California has a patent on the cell line, no licence has ever been granted on the patent, to Genetics Institute, Sandoz or any other party. Second, I received stock in Genetics Institute as compensation for my work over a seven-year period as a founding scientific consultant to the company, not in return for providing access to the cell line. The university, which owns the cell line, arranged with Genetics Institute to provide access to the cell line before a patent was issued, in exchange for research funding in a collaborative research agreement. Since the issue of the patent in 1984, the cell line has been available to any qualified investigator from the American Type Culture Collection, Rockville, Maryland. However, because the cell line produces the human retrovirus, HTLV-II, it must be treated as potentially hazardous material.

DAVID W. GOLDE

UCLA School of Medicine,

Center for the Health Sciences,

Los Angeles, California 90024, USA 